\title{
PENGARUH HARGA, PROMOSI, PRODUK, LABEL HALAL TERHADAP KEPUTUSAN MEMBELI FROZEN FOOD
}

\author{
(Studi di Kota Bengkulu)
}

\author{
Lupi Ayu Lestari, Yustika Apriani, Asnaini, Kustin \\ Prodi Ekonomi Syariah, Fakultas Ekonomi Bisnis dan Islam \\ Institut Agama Islam Negeri \\ Email: lupiayulestari23@gmail.com, yustikaapriani21@gmail.com \\ asnaasnaini@gmail.com, kustinhartini@gmail.com
}

\begin{abstract}
Abstak
Tujuan dari penelitian ini adalah untuk mengetahui pengaruh Harga, Promosi, Produk, Label Halal secara parsial dan simultan terhadap keputusan pembelian Frozen food. Jenis penelitian ini adalah penelitian kuantitatif asosiatif. Populasi dalam penelitian ini adalah seluruh konsumen di Kota Bengkulu yang membeli makanan beku dalam jumlah yang tidak diketahui. Metode pengambilan sampel menggunakan teknik accidental sampling. jumlah sampel dalam penelitian ini ditentukan sebanyak 115 sampel. Metode analisis data yang digunakan adalah metode analisis regresi linier berganda. Hasil penelitian ini menunjukkan bahwa secara parsial variabel harga (X1) berpengaruh signifikan terhadap keputusan pembelian Frozen Food dengan nilai t hitung sebesar 2,563 > t tabel 1,65857 dan nilai signifikansi $0,012<0,05$, dan Promosi ( X2) juga berpengaruh signifikan terhadap keputusan membeli Frozen. Makanan dengan nilai t-hitung 2,796 > t-tabel 1,65857 dan nilai signifikansi 0,006 < 0,05, dan produk (X3) juga berpengaruh signifikan terhadap keputusan pembelian Frozen Food dengan nilai t-hitung 3,892 > t -tabel 1,65857 dan nilai signifikansi $0,000<0,05$, dan Label Halal (X4) berpengaruh signifikan terhadap keputusan pembelian Frozen Food dengan nilai dan $\mathrm{t}$ hitung sebesar 4,757>t tabel 1,65857 dan nilai signifikansi sebesar 0,000 $<0,05$. Secara keseluruhan menunjukkan bahwa harga, promosi, produk, dan label halal berpengaruh signifikan terhadap keputusan pembelian frozen food dengan nilai F hitung 51,360 > F tabel 3,08.
\end{abstract}

\section{Kata Kunci: Harga, Promosi, Produk, Label Halal}

\section{PENDAHULUAN}

Harga adalah faktor konsumen untuk menentukan keputusan pembelian. Pengaruh harga terhadap keputusan pembelian penting karena dengan tingkat harga yang ditetapkan oleh perusahaan dapat menjadi tolak ukur akan permintaan suatu produk penetapan harga yang salah dalam suatu produk dapat menyebabkan jumlah penjualan pada suatu produk tidak dapat maksimal yang mengakibatkan penjualan menurun dan pangsa pasarnya berkurang, harus dapat menentukan harga penjualan sesuai dengan 
pangsa pasar yang dituju agar penjualan produk dan pangsa pasar yang meningkat (kotler 2009:67). ${ }^{1}$

Munculnya produk-produk baru di Indonesia membuat tantangan tersendiri bagi para produsen. Berbagai macam strategi dijalankan, mulai dari beriklan di televisi, radio, koran, dan media sosial seperti facebook, twitter, website, dan instagram, ada juga penjual yang menggunakan strategi dalam bentuk multilevel marketing dengan sistem down line dan up line, penjualan dengan cara sampling produk (coba rasa) yang di lakukan SPG atau SPB.

Di indonesia $90 \%$ penduduknya muslim seharusnya bisa menjaga nilai-nilai agama termasuk dalam hal mengkonsumsi makanan, sebagai umat yang beragama tentu saja hal ini tetap menjadi dasar bagi umatnya dalam berperilaku. Masyarakat perlu berhati-hati dalam memilih produk tersebut, bagi umat muslim kesalahan dalam memilih produk makanan yang dikonsumsi dapat menyebabkan kerugian lahir dan batin. Secara lahir mengkonsumsi produk yang mengandung bahan berbahaya dapat menggangu kesehatan, sedangkan secara batin mengkonsumsi produk yang tidak halal dapat menimbulkan dosa. hal yang perlu di perhatikan oleh konsumen sebelum mengkonsumsi suatu produk adalah memahami bahasa/tulisan, nomor pendaftaran nama produk, label halal, daftar bahan yang digunakannya. ${ }^{2}$

Labelisasi halal merupakan pencantuman atau persyaratan halal pada kemasan produk untuk menunjukkan bahwa produk tersebut benar-benar halal dan bahan-bahan yang dikandungnya tidak mengandung unsur-unsur yang diharamkan. Dengan demikian produk-produk yang tidak mencantumkan label halal pada produknya, dianggap belum mendapatkan persetujuan oleh lembaga yang berwenang (LPPOMMUI) untuk diklasifikasikan dalam produk yang halal atau dianggap masih diragukan kehalalannya (Alfian \& Marpuang, 2017:126). Banyak penjual yang tidak mencantumkan lebal halal pada kemasannya serta bahan campurannya tidak di ketahui. di kota kota besar di luar bengkulu banyak kasus pengoplosan daging sapi dan daging celeng. Tetapi masyarakat di kota bengkulu tidak terlalu peduli terhadap kemasan dan bahan campuran yang berlabel halal, minat masyarakat di kota bengkulu masih banyak pemesanan melalui media social. Peneliti merujuk pada bagaimana konsumen membuat keputusan Ketika membeli frozen food yang pada dasarnya masyarakat hanya melihat dari harga tanpa mempertimbangkan Kembali ke halalan suatu produk.

Sejarahnya Frozen food (makanan beku) sudah ada sejak sekitar 3000 tahun sebelum masehi, ketika masyarakat cina kuno mulai bisa menggunakan es untuk mempertahankan makanannya di sepanjang musim dingin. Begitu pula orang romawi yang dapat menggunakan salju untuk membekukan makanannya. Untuk pertama kalinya

${ }^{1}$ Suri amalia,m,Oloan asmara nst "pengaruh citra merek, harga,dan kualitas produk terhadap keputusan pembelian handphone merek xiaomi di kota langsa"jurnal manajemen dan keuangan, VOL 6, NO 1, MEI 2017 ISSN 2252-844X. h. 661

${ }^{2}$ Cristianlasander" citra merek, kualitas produk,dan promosi pengaruh terhadap kepuasan konsumen pada makanan tradisional" JURNAL EMBA VOL.1NO.3 september 2013, h,284-293 
pada 1930 di springfield, massachusetts, seorang yang bernama clarence birdseye sudah memperkenalkan makanan beku berupa sayuran buah-buahan, seafoods, dan daging yang djiual kepada masyarakat. Di indonesia makanan beku mulai dapat diperkenalkan oleh orang-orang cina dan jepang. Frozen food (Makanan beku) adalah makanan yang diolah lalu dikemas ke dalam kemasan dengan keadaan setengah matang dan apabila di konsumsi harus melalui proses pengolahan kembali yaitu dengan cara memanaskan di penggorengan (Bisnisukm,2014). Makanan beku juga didefenisikan sebagai makanan yang di bekukan dengan tujuan untuk mengawetkan makanan hingga siap untuk dimakan. Frozen food bisa jadi solusi bagi yang tidak ingin repot dalam memasak, banyak orang memilih Frozen food karena praktis dan siap saji, tetapi ada juga dampak negatifnya bagi kesehatan bisa menyebabkan diabetes, penyakit jantung, tekanan darah, kanker. meski tahan lama produk pangan yang di bekukan tetap mempunyai batas waktu daya simpan, makanan beku dilapisi dengan bahan kimia yang berbahaya.

Penelitian terdahulu yang dilakukan oleh sarini kodu yang berjudul harga, kualitas produk dan kualitas pelayanan pengaruhnya terhadap keputusan pembelian mobil toyota avanza. Penelitian ini bertujuan untuk mengetahui pengaruh harga, kualitas produk dan kualitas pelayanan terhadap keputusan pembelian. Hasil penelitian ini menujukkan bahwa harga, kualitas produk dan kualitas pelayanan secara simultan maupun parsial berpengaruh signifikan terhadap keputusan pembelian.

Sandi sinambow dan irvan trang melakukan penelitian yang berjudul pengaruh harga, lokasi, promosi dan kualitas layanan terhadap keputusan pembelian pada toko komputer game zone mega mall manado. Penelitian ini bertujuan untuk mengetahui pengaruh harga ,lokasi, promosi dan kuliatas layanan terhadap keputusan pembelian pada toko komputer game zone mega mall manado. Hasil penelitian ini menunjukkan secara simultan dan parsial harga, lokasi, promosi dan kualitas layanan berpengaruh positif dan signifikan terhadap keputusan pembelian. ${ }^{3}$

Debby wijaya L melakukan penelitian yang berjudul faktor-faktor yang menpengaruhi konsumen rumah tangga terhadap pembelian produk chicken frozen food di kota palembang. Penelitian ini bertujuan untuk mengetahui faktor-faktor yang menpengaruhi konsumen rumah tangga terhadap pembelian produk chicken frozen food di kota palembang. Penelitian ini mengunakan metode survei konsumen, dengan metode penarikan contoh menggunakan multi stage random sampling dan accindental sampling technque. Sedangkan, metode penggelolaan data yang digunakan ialah analisi regresi linear berganda dan analisi penilaian konsumen. ${ }^{4}$

Penelitian yang dilakukan lovell (2011) menunjukkan bahwa faktor rasa menjadi pertimbangan utama bagi konsumen unruk menentukan suatu produk frozen food di thailand, diikuti oleh kemudahan, kemasan, harga, merek dan waktu penyajian. Penelitian

\footnotetext{
${ }^{3}$ Tengku putri lindang bulan "pengaruh lebelisasi halal terhadap keputusan pembelian sosis di kuala simpang kabupaten aceh tamiang” jurnal manajemen dan keuangan VOL.5, NO 1 mei 2016, h. 430-431

${ }^{4}$ Muhammad ulil abshor,Leonardo B Hasiolan, SE,M.MP, Djamaludin malik S.Pd M.SP "pengaruh harga, promosi dan kualitas produk terhadap keputusan pembelian produk torabika duo"h.32-34
} 
yang dilakukan oleh abdullah (2011) dan ismoyowati (2015), menunjukkan faktor halal menjadi faktor yang penting bagi konsumen di ikuti oleh harga, kualitas layanan dan merek.

Christopher richie rahardjo melakukan penelitian yang berjudul faktor yang menjadi preferensi konsumen dalam membeli produk frozen food. Tujuan penelitian ini untuk mengetahui faktor apa saja yang menjadi preferensi konsumen dalam membeli produk frozen food. Penelitian ini menggunakan metode kualitatif dan data yang digunakan pada penelitian di peroleh melalui survei kepada 40 konsumen frozen food. Hasil penelitian ini menunjukkan bahwa faktor yang paling penting dalam mempengaruhi preferensi konsumen dalam memilih produk frozen food berturut-turut adalah rasa, harga, kemasan dan merek. ${ }^{5}$

Berdasarkan latar belakang masalah yang telah dipaparkan di atas, maka penulis tertarik untuk meneliti judul "Pengaruh Harga, Promosi, Produk, Label Halal terhadap Keputusan Membeli Frozen Food (Studi Kasus di kota Bengkulu)".

Tujuan dari penelitian ini adalah untuk mengetahui pengaruh Harga, Promosi, Produk, Label Halal secara persial dan simultan terhadap keputsan membeli frozen food.

\section{TINJAUAN PUSTAKA}

\section{A. Keputusan Membeli}

Keputusan membeli merupakan pemikiran dimana individu mengevaluasi berbagai pilihan dan memutuskan pilihan pada suatu produk dari sekian banyak pilihan. keputusan membeli adalah tahap dalam proses pengambilan keputusan pembeli di mana konsumen benar-benar membeli (Kotler \& Amstrong 2014). keputusan membeli merupakan proses dimana konsumen melewati lima tahap, yaitu pengenalan masalah, pencarian informasi, evaluasi alternatif, keputusan membeli, dan perilaku pasca membeli, yang dimulai jauh sebelum membeli aktual dilakukan dan memiliki dampak yang lama setelah itu (Kotler dan Keller 2012:227). keputusan membeli konsumen merupakan tindakan individu yang secara langsung dan tidak langsung terlibat dalam usaha memperoleh dan menggunakan suatu produk atau jasa yang dibutuhkan (Tjiptono 2008). ${ }^{6}$

Dalam memahami perilaku konsumen, terdapat banyak pengaruh yang mendasari seseorang dalam mengambil keputusan membeli suatu produk atau merek. Pada kebanyakan orang, perilaku membeli konsumen seringkali diawali dan dipengaruhi oleh banyaknya rangsangan (stimuli) dari luar dirinya, baik berupa rangsangan pemasaran maupun rangsangan dari lingkungan yang lain. Rangsangan tersebut kemudian diproses (diolah) dalam diri, sesuai dengan karakteristik pribadinya, sebelum akhirnya diambil keputusan membeli.

\section{B. Harga}

${ }^{6}$ Ainur rizki putra "pengaruh harga,lebel halal,pelayanan, promosi dan lokasi terhadap keputusan pembelian" skripsi UIN syarif hidayatullah Jakarta 2018, h.33-35 
Harga merupakan faktor utama penentuan posisi dan harus diputuskan sesuai dengan pasar sasaran, bauran ragam produk, dan pelayanan, serta persaingan. Harga merupakn komponen yang berpengaruh langsung terhadap perusahaan. harga adalah nilai yang disebutkan dalam mata uang (rupiah) atau medium moneter lainnya sebagai alat tukar (price is value expressed in terms of dollar or monetary medium of exchange (bruce j. Walker). harga adalah salah satu unsur bauran pemasaran yang menghasilkan pendapatan dan unsur-unsur lainnya yang menghasilkan biaya (philip kotler). ${ }^{7}$

Para ulama dari mazhab terkenal yaitu hambali dan syafi'i menyatakan bahwa pemerintah tidak mempunyai hak untuk menetapkan harga. Ibnu Al-Maqdisi adalah salah seorang ulama bermazhab Hambali menulis bahwa imam (pemimpin pemerintah) tidak memiliki wewenang untuk mengatur harga bagi penduduk. Penduduk boleh menjual barang-barang mereka dengan harga berapa pun yang mereka sukai.

Ibnu Qudamah beralasan dari hadist yang diriwayatkan Abu Hurairah r.a yang menyatakan: bahwa ada seorang laki-laki datang lalu berkata, wahai rasulullah SAW, tetapkan lah harga ini, maka beliau menjawab: tidak, justru biarkan lah saja kemudian beliau didatangi oleh laki-laki yang lain mengatakan, wahai rasulullah SAW, tetapkan lah harga ini, maka beliau menjawab, "tidak tetapi Allah-lah yang berhak menurunkan dan menaikkan".

Ibnu Qudamah mengutip hadits diatas memberikan dua alasan tidak diperkenankan mengatur harga:

a. Rasulullah SAW tidak pernah menetapkan harga, meskipun penduduk menginginkannya. Bila itu diperbolehkan pasti rasulullah akan melaksankannya.

b. Menetapkan harga adalah suatu ketidakadilan (dhalim) yang dilarang. Ini melibatkan hak milik seseorang didalamya. Setiap orang memiliki hak untuk menjual pada harga berapa pun asal ia sepakat dengan pembeliannya.

\section{Promosi}

Promosi adalah berbagai kumpulan alat-alat intensif yang sebagian besar berjangka pendek, yang dirancang untuk merangsang pembelian produk atau jasa tertentu denga lebih cepat dan lebih besar oleh konsumen atau pedagang (kotler, 2007:266 dalam mandey 2013). Promosi adalah berbagai cara untuk menginformasikan, membujuk, dan mengingatkan konsumen secara langsung maupun tidak langsung tentang suatuproduk atau brand yang di jual (kotler, 2007:266 dalam mandey 2013). promosi adalah suatu komunikasi dari penjual dan pembeli yang berasal dari informasi yang tepat yang bertujuan untuk mengubah sikap dan tingkah laku pembeli, yang tadinya tidak mengenal menjadi mengenal sehingga menjadi pembeli dan tetap dan mengingat produk itu (Laksana,2008:133). ${ }^{8}$

${ }^{7}$ Stephanus felix aristo "pengaruh produk,harga,dan promosi terhadap keputusan pembeliaan konsumen woles chips "jurnal manajemen dan start-up bisnis volume 1, nomor 4,oktober 2016 h.441-447

${ }^{8}$ Nela Evelina, Handoyo DW, Sari Listyorini "PENGARUH CITRA MEREK, KUALITAS PRODUK,HARGA,DAN PROMOSI TERHADAP KEPUTUSAN 
Ada beberapa etika yang harus diperhatikan dalam mempromosikan produk sesuai dengan ajaran islam yaitu: (Asmida,2017:35).

1. Jangan mudah mengobral sumpah

Dalam melakukan promosi atau iklan janganlah mudah mengucapkan janji sekiranya janji tidak bias ditepati. Dari Abu Qatadah Al-Anshori, Nabi Muhammad SAW bersabda:

"Dari Abu Qatadah Al-Anshori, bahwasannya ia mendengar Rasulullah SAW besabda: hati-hatilah dengan banyak bersumpah dalam menjual dagangan karena ia memang melariskandagangan, namun menghapuskan keberkahan". (HR Ibnu Majah) shahih At-Ta'liq Ar-Raghib (Nawawi,1999:548). ${ }^{9}$

2. Jujur

Islam sangat melarang memalsukan dan menipu karena dapat menyebabkan kerugian dan kezaliman serta dapat menimbulkan permusuhan dan percekcokan seperti yang dijelaskan dalam hadits dibawah ini:

"Dari Abdullah r.a berkata Rasulullah SAW bersabda. Sesungguhnya berkata benar itu menunjukkan kepada kebaikan dan sesungguhnya kebaikan itu menunjukkan kepada surga. Sesungguhnya seseorang suka berkata benar sampai dituliskan menjadi orang amat benar. Dan sesungguhnya dusta itu menunjukkan kepada kejahatan dan sesungguhnya kejahatan itu menunjukkan neraka. Sesungguhnya orang suka berdusta sehingga menjadi orang yang amat pendusta”. (HR, Muslim) (an-Nawawi, 2011:580).

3. Menjaga agar selalu memenuhi akad dan janji seta kesepakatan-kesepakatan diantara kedua belah pihak yaitu pembeli dan penjual. Allah SWT berfirman pada QS Al-Maidah ayat 1:

Terjemahannya:

"Hai orang-orang yang beriman, penuhilah akad-akad itu. Dihalalkan bagimu binatang ternak, kecuali yang akan dibacakan kepadamu. (yang demikian itu) dengan tidak menghalalkan berburu ketika kamu sedang mengerjakan haji. Sesunggunhyan allah menetapkan hukum-hukum menurut yang dikehendaki-Nya". (QS Al-Maidah: 1) (R1. 2002:106).

4. Menghindari promosi palsu dengan tujuan menarik perhatian pembeli dan mendorongnya untuk membeli.

PEMBELIAN KARTU PERDANA TELKOMSEL" diponegoro journal of social and politic tahun 2012,h .1-11

${ }^{9}$ Jackson R.S weenas "kualitas produk,harga,promosi dan kualitas pelayanan pengaruhnya terhadap keputusaan pembelian spring bed comforta" JURNAL EMBA vol.1, no 4 desember 2013, h 67-618 
5. Rela dengan laba yang sedikit karena itu akan mengundang kepada kecintaan manusia dan menarik banyak pelanggan serta rezeki yang kita dapatkan di ridhoi Allah SWT.

\section{Produk}

Setiap perusahaan akan berusaha untuk memenuhi kebutuhan dan keinginan konsumen dengan menyediakan produk yang ada. Produk merupakan suatu sifat yang komplek baik dapat diraba maupun tidak dapat diraba, termasuk bungkus, warna, harga, prestise perusahaan dan pengecer, yang diterima oleh pembeli untuk memuaskan keinginan dan kebutuhannya (Basu Swasta,1996:94). Produk adalah segala sesuatu yang ditawarkan produsen untuk diperhatikan, diminta, dicari, dibeli, digunakan atau dikonsumsi yang meliputi mutu/kualitas, pilihan yang ada (options), merek (brand names), pengemasan (packaging), macam (product items), ukuran (sizes), jenis (product lines), dan jaminan (Sofjan Assauri,2004:200). produk merupakan segala sesuatu yang dapat ditawarkan produsen untuk di perhatikan diminta, dicari, dibeli, digunakan atau dikonsumsi pasar sebagai pemenuhan kebutuhan atau keinginan pasar yang bersangkutan (Tjiptono F.2008:95,103), ${ }^{10}$

\section{E. Label Halal}

Label adalah merek sebagai nama, istilah, tanda, lambang, atau desain, atau kombinasinya, yang dimaksudkan untuk mengidentifikasi barang atau jasa dari salah satu penjual atau kelompok penjual dan mendiferensiasikan mereka dari para pesaing (Kotler \& Armstrong, 2010;414). ${ }^{11}$ Label halal adalah pemberian tanda halal atau bukti tertulis sebagai jaminan produk yang halal dengan tulisan halal dalam Bahasa Arab, huruf lain dan motor kode dari menteri agama yang di keluarkan atas dasar pemeriksaan halal dari lembaga pemeriksa halal yang dibentuk oleh MUI, farwa halal dari MUI, sertifikat halal dari MUI sebagai jaminan yang sah bahwa produk yang dimaksud adalah halal dikonsumsi serta digunakan oleh masyarakat sesuai dengan ketentuan syariah (Alfian \& Marpuang, 2017:126). Sertifikat halal adalah pengakuan kehalalan suatu produk yang dikeluarkan oleh BPJPH baredasarkan fatwa halal tertulis yang dikeluarkan oleh MUI, berdasarkan peraturan pemerintah nomor 69 tahun 1999, tentang label halal dan iklan pangan adalah setiap keterangan mengenai pangan yang berbentuk gambar, tulisan, kombinasi keduanya atau bentuk lain yang disertakan dalam pangan, dimasukkan ke dalam, ditempelkan pada atau merupakan bagian kemasan pangan.

${ }^{10}$ Stephanus felix aristo "pengaruh produk, harga,dan promosi terhadap keputusan pembeliaan konsumen woles chips "jurnal manajemen dan start-up bisnis volume 1, nomor 4,oktober 2016 h.441-447

${ }^{11}$ Muhammad ulil abshor,Leonardo B Hasiolan, SE,M.MP, Djamaludin malik S.Pd M.SP "pengaruh harga, promosi dan kualitas produk terhadap keputusan pembelian produk torabika duo"h.35-45 
Sertifikat halal adalah fatwa tertulis MUI yang menyatakan kehalalan suatu produk sesuai dengan syariat islam. Sertifikat halal ini merupakan syarat untuk mencantumkan label halal (Adisasmito, 2008:23). Adapun beberapa produk yang memenuhi syarat kehalalan sesuai dengan syariat islam, yaitu:

1. Tidak mengandung babi dan bahan yang berasal dari babi.

2. Tidak mengandung bahan-bahan yang diharamkan seperti: bahan-bahan yang berasal dari organ manusia, darah, kotor-kotoran, dan lain sebagainya.

3. Semua bahan yang berasal dari hewan halal yang disembelih menurut tata cara syariat islam.

4. Semua tempat penyimpanan, tempat penjualan, pengelolaan, tempat pengelolaan dan transportasinya tidak boleh digunakan untuk babi. Jika pernah digunakan untuk babi atau barang yang tidak halal lainnya terlebih dahulu harus dibersihkan dengan tata cara yang di atur dalam syariat islam.

5. Semua makanan dan minuman tidak mengandung khamar.

\section{Metodelogi Penelitian}

\section{A. Lokasi penelitian}

Penelitian ini dilakukan terhadap masyarakat di Agen Frozen food Bengkulu "Fafana Frozen" Jalan danau NO.21, Panorama, Kec. Singaran Pati, Kota Bengkulu.

\section{B. Jenis dan Pendekatan penelitian}

Jenis penelitian ini menggunakan jenis penelitian lapangan dan pendekatan yang digunakan dalam penelitian ini adalah dengan menggunakan pendekatan kuatitatif asosiatif, untuk mengetahui ada atau tidaknya pengaruh terhadap harga, promosi, produk, label halal sebagai variabel indenpent dan keputusan membeli sebagai variabel dependent. $^{12}$

Teknik pengumpulan data yang dilakukan dalam penelitian ini adalah dengan menggunakan kuesioner yaitu dengan cara membuat daftar pertanyaan untuk diisi oleh responden.

\section{Populasi dan Sampel}

\section{Populasi}

populasi adalah generalisasi yang terdiri dari atas objek atau subjek mempunyai kuantitas dan karakteristik tertentu yang di tetapkan oleh peneliti untuk dipelajari dan kemudian ditarik kesimpulannya (Sugiyono 2012). ${ }^{13}$ Populasi dalam penelitian ini adalah

${ }^{12}$ Cooper, Donald R.C dan emory, William. "metode penelitian bisnis" erlangga Jakarta 1998. h.50-60

${ }^{13}$ Sugiyono "Metode Penelitian Kombinasi (Mix Methods) bandung 2015. Alpebeta. 
seluruh Masyarakat di Kota Bengkulu yang membeli frozen food yang tidak diketahui jumlahnya.

\section{Sampel}

Sampel merupakan bagian dari jumlah dan karakteristik populasi penelitian. Dalam penelitian ini teknik pengambilan sampel menggunakan teknik Accidental sampling. Accidental sampling adalah teknik pengambilan sampel secara kebetulan dimana semua anggota populasi mempunyai peluang yang sama untuk dijadikan anggota sampel (Sugiyono 2009). Menurut Hair et al (2010) menyatakan bahwa jumlah ideal dalam penarikan sampel 5-10 untuk setiap indikator yang digunakan dalam seluruh variabel. ${ }^{14}$ Jumlah indikator dalam penelitian adalah 23 indikator. Maka, jumlah sampel dalam penelitian ini adalah :

Sampel minimum = Jumlah Indikator $\mathrm{x} 5$

$=23 \times 5=115$ responden

Maka jumlah sampel dalam penelitian ini ditentukan sebanyak 115 sampel, yang dirasa sudah cukup mewakili populasi.

\section{Teknik Analisis Data}

Analisis data yang dilakukan dengan analisis ststistic dan menggunakan sofware SPSS 16. Pengujian dalam penelitian ini adalah uji validitas, uji reabilitas, uji normalitas, uji multikolinearitas, uji regresi linear berganda, koefisien determinasi, Uji t dan Uji F.

\section{E. Hipotesis Penelitian}

Hipotesis merupakan jawaban sementara rumusan-rumusan masalah penelitian (Sugiyono, 2010), adapun hipotesis dalam penelitian ini adalah :

H1: Harga berpengaruh secara signifikan terhadap Keputusan membeli frozen food di kota Bengkulu.

H2: Promosi berpengaruh secara signifikan terhadap Keputusan membeli frozen food di kota Bengkulu.

H3: Produk berpengaruh secara signifikan terhadap Keputusan membeli frozen food di kota Bengkulu.

H4: Label halal berpengaruh secara signifikan terhadap Keputusan membeli frozen food di kota Bengkulu.

H5: Harga, promosi, produk, label halal berpengaruh secara bersamaan terhadap Keputusan membeli frozen food di kota Bengkulu.

\section{Uji Validitas}

Pengujian validitas dalam penelitian ini menggunakan komputer dengan bantuan program SPSS.Berdasarkan tabel di atas maka dapat dilihat bahwa semua indikator yang digunakan dalam penelitian memiliki nilai validitas $\mathrm{r}$ hitung $>\mathrm{r}$ tabel, maka semua indikator dikatakan valid dan dapat digunakan dalam penelitian.

\footnotetext{
${ }^{14}$ Sugiyono "Metode Penelitian pendidikan pendekatan Kuantitatif, Kualitatif dan
} R\&D” Bandung 2010. Albepata 


\section{Uji Reabilitas}

Berdasarkan nilai Cronbach Alpha lebih besar daripada taraf signifikan 0,6. sehingga dapat disimpulkan bahwa instrumen dalam penelitian ini reliabel artinya bahwa butir-butir pernyataan pada kuesioner andal untuk mengukur variabelnya sehinga penelitian dapat dilanjutkan.

\section{Uji Asumsi Klasik}

\section{a. Uji Normalitas}

menunjukan bahwa grafik uji normalitas mengambarkan penyebaran data disekitar garis diagonal dan penyebarannya mengikuti arah garis diagonalgrafik tersebut, makam model regresi yang digunakan dalam penelitian ini mengurus asumsi normalitas.

\section{b. Uji multikolineritas}

Berdasarkan semua variabel memiliki nilai toleransi 0,1 dan nilai VIF dibawah 10, dengan demikian dapat disimpulkan bahwa variabel pada penelitian bebas multikolinieritas. $^{15}$

\section{Uji Hipotesis}

\section{a. Analisis regresi linear berganda}

Analisis regresi linear berganda yang akan dibahas dalam penelitian ini sehingga dapat menggambarkan tanggapan responden (Harga, Promosi, Produk dan Label Halal) terhadap Keputusan membeli Frozen Food di kota Bengkulu. Maka hasil uji regresi linier berganda dapat dilihat pada table 4.7 dibawah ini :

Table 4.7

\section{Hasil Analisis Regresi Linear Berganda}

\section{Coefficients $^{\mathrm{a}}$}

\begin{tabular}{|c|c|c|c|c|c|}
\hline \multirow[b]{2}{*}{ Model } & \multicolumn{2}{|c|}{ Unstandardized Coefficients } & \multirow{2}{*}{$\begin{array}{c}\begin{array}{c}\text { Standardized } \\
\text { Coefficients }\end{array} \\
\text { Beta }\end{array}$} & \multirow[b]{2}{*}{$\mathrm{t}$} & \multirow[b]{2}{*}{ Sig. } \\
\hline & $\mathrm{B}$ & Std. Error & & & \\
\hline 1 (Constant) & 2.266 & 1.072 & & 2.114 & .037 \\
\hline Harga & .222 & .087 & .201 & 2.563 & .012 \\
\hline
\end{tabular}

${ }^{15}$ Imam Ghozali “Aplikasi Analisis Multi variat dengan program IBM SPSS 20" Penerbit Universitas Di ponegoro. Semarang, 2012. 


\begin{tabular}{|l|r|r|r|r|r|}
\hline Promosi & .213 & .076 & -.296 & -2.796 & .006 \\
Produk & .345 & .089 & .372 & 3.892 & .000 \\
label_hala & .487 & .102 & .569 & 4.757 & .000 \\
\hline
\end{tabular}

a. Dependent Variable: keputusan_membeli

Sumber: Output SPSS 16 berikut :

Dari perhitungan hasil diatas didapatkan persamaan regresinya adalah sebagai $\mathrm{Y}=2.266+222(\mathrm{X} 1)+213(\mathrm{X} 2)+345(\mathrm{X} 3)+487(\mathrm{X} 4)$

Berdasarkan persamaan regresi diatas, maka dapat menyatakan sebagai berikut :

1) Nilai Konstanta 2.266 mempunyai arti bahwa persamaan variabel Harga (X1), Promosi (X2), Produk (X3), Label Halal (X4) terhadap Keputusan membeli (Y) sama dengan nol, maka variabel Keputusan membeli akan tetap yaitu 2.266 apabila variabel Harga (X1), Promosi (X2), Produk (X3), dan Label Halal (X4) sama dengan nol.

2) Koefisien Regresi X1, sebesar 222 mempunyai makna jika nilai variabel Harga (X1) naik satu satuan maka nilai Keputusan membeli (Y) akan naik sebesar 222 dengan asumsi variabel Promosi (X2), Produk (X3) dan Label Halal (X4) dianggap tetap.

3) Koefisien Regresi X2, sebesar 213 mempunyai makna jika nilai variabel Promosi (X2) naik satu satuan maka nilai variabel Keputusan pembelian (Y) akan naik sebesar 213 dengan asumsi variabel Harga (X1), Produk (X3) dan Label Halal (X4) dianggap tetap.

4) Koefisien Regresi X3, sebesar 345 mempunyai makna jika nilai variabel Produk (X3) naik satu satuan maka nilai Keputusan membeli (Y) akan naik sebesar 345 dengan asumsi variabel Harga (X1), Promosi (X2), dan Label Halal (X4) dianggap tetap. $^{16}$

5) Koefisien Regresi X4, sebesar 487 mempunyai makna jika nilai variabel Label Halal (X4) naik satu satuan maka nilai Keputusan membeli (Y) akan naik sebesar 487 dengan asumsi variabel Harga (X1), Promosi (X2), dan Produk (X3) dianggap tetap.

\section{b. Uji F}

Melalui perhitungan yang dilakukan dengan menggunakan program SPSS, maka perbandingan fhitung dengan ftabel $(\mathrm{Df}=\mathrm{n}-\mathrm{k}-1)=115-2-1=112$ (3.08) setiap variabel sebagai berikut :

${ }^{16}$ Imam Ghozali "Aplikasi Analisis Multi variat dengan program IBM SPSS 20” Penerbit Universitas Di ponegoro. Semarang, 2012. 
Berdasarkan tabel uji hipotesis dengan uji F diatas yaitu ( $\operatorname{sig}<\alpha=0.000<0,05)$ dan Fhitung $51.360>$ Ftabel 3.08. Maka dapat dibuktikan bahwa Harga $\left(\mathrm{X}_{1}\right)$, Promosi $\left(\mathrm{X}_{2}\right)$, Produk $\left(\mathrm{X}_{3}\right)$ dan Label Halal $\left(\mathrm{X}_{4}\right)$, secara bersama-sama atau simultan berpengaruh signifikan terhadap terhadap keputusan membeli Frozen Food di Kota Bengkulu. ${ }^{17}$

\section{c. Uji t}

Melalui perhitungan yang dilakukan dengan menggunakan program SPSS, maka perbandingan thitung dengan ttabel $(\mathrm{Df}=\mathrm{n}-\mathrm{k}-1)=115-2-1=112$ (1.65857) setiap variabel sebagai berikut :

1) Variabel Harga (X1), yaitu ( $\operatorname{sig}<\alpha=0,012<0,05$ ) dan thitung $2.563>$ ttabel 1.65857. Maka H1 yang menyatakan bahwa Harga berpengaruh signifikan terhadap keputusan membeli Frozen Food di Kota Bengkulu, diterima.

2) Variabel Promosi $\left(\mathrm{X}_{2}\right)$ yaitu ( $\left.\operatorname{sig}<\alpha=0,006<0,05\right)$ dan thitung $2.796>$ ttabel 1.65857. maka H2 yang menyatakan bahwa Promosi berpengaruh signifikan terhadap keputusan membeli Frozen Food di Kota Bengkulu, diterima.

3) Variabel Produk $\left(\mathrm{X}_{3}\right)$ yaitu (sig $\left.<\alpha=0,000<0,05\right)$ dan thitung $3.892>$ ttabel 1.65857. maka H3 yang menyatakan bahwa Produk berpengaruh signifikan terhadap keputusan membeli Frozen Food di Kota Bengkulu, diterima.

4) Variabel Label Halal $\left(\mathrm{X}_{4}\right)$ yaitu ( $\left.\operatorname{sig}<\alpha=0,000<0,05\right)$ dan thitung $4.757>$ ttabel 1.65857. maka H4 yang menyatakan bahwa Label Halal berpengaruh signifikan terhadap keputusan membeli Frozen Food di Kota Bengkulu, diterima.

\section{d. Koefisien Determinasi (R2)}

Berdasarkan tabel dapat diketahui nilai koefisien determinasi (R2) basar 0.807 ini menandakan bahwa hubungan antar variabel Harga, Pomosi, Produk dan Label Halal adalah kuat dan signifikan. Dan koefisien determinasi (R square) R2 $=0.651$ dimana nilai koefisien determinasi tersebut mempunyai arti bahwa secara bersama-sama variabel Harga, Pomosi, Produk dan Label Halal memberikan sumbangan dalam mempengaruhi Keputusan pembelian pada Frozen Food di Kota Bengkulu sebesar $65.1 \%$ sedangkan sisanya $67,3 \%$ dipengaruhi oleh variabel lain yang tidak masuk dalam model penelitian.

\section{HASIL PENELITIAN}

\section{A. Pengaruh Harga $\left(X_{1}\right)$ Terhadap Keputusan membeli $Y$}

Harga memiliki pengaruh yang signifikan terhadap Keputusan Membeli. Hal tersebut dihasilkan dari hasil pengujian pada Uji t dengan nilai signifikansi yaitu sebesar (sig $<\alpha=0.012<0,05$ ) dan nilai thitung $2.563>$ ttabel 1.65847. maka H1 yang menyatakan bahwa Harga mempunyai pengaruh yang signifikan terhadap Keputusan membeli Frozen Food di Kota Bengkulu, diterima. Hal ini sejalan dengan hasil penelitian yang dilakukan Muhammad Ulil Abshor, Leonando B Hasiolan, S.E, M.M, Djamaludin Malik S.Pd M.Si yang menyatakan bahwa Harga Terhadap Keputusan membeli berpengaruh positif dan signifikan. Di penelitian lain yang dilakukan Sandi sinambow

${ }^{17}$ Gunjarati, S ”Ekonometrika Terapan” Erlangga, Jakarta 2021 
dan irvan trang mengemukakan bahwa variabel Harga berpengaruh secara positif dan signifikan terhadap Keputusan membeli.

\section{B. Pengaruh Promosi (X2) Terhadap Keputusan membeli Y}

Promosi memiliki pengaruh yang signifikan terhadap Keputusan Membeli. Hal tersebut dihasilkan dari hasil pengujian pada Uji t dengan nilai signifikansi yaitu sebesar $(\operatorname{sig}<\alpha=0.006<0,05)$ dan nilai thitung $2.796>$ ttabel 1.65847. maka H2 yang menyatakan bahwa Promosi mempunyai pengaruh yang signifikan terhadap Keputusan membeli Frozen Food di Kota Bengkulu, diterima. Berdasarkan hasil penelitian yang dilakukan oleh Arief adi menyatakan bahwa promosi berpengaruh secara simultan terhadap keputusan membeli. Di penelitian lain yang dilakukan Jilly Bernadette mandey Jurnal Emba (2013) bahwa variabel Promosi berpengaruh secara positif dan signifikan terhadap Keputusan membeli.

\section{Pengaruh Produk (X3) Terhadap Keputusan membeli Y}

Produk memiliki pengaruh yang signifikan terhadap Keputusan Membeli. Hal tersebut dihasilkan dari hasil pengujian pada Uji t dengan nilai signifikansi yaitu sebesar ( $\operatorname{sig}<\alpha=0.000<0,05)$ dan nilai thitung $3.892>$ ttabel 1.65847. maka H3 yang menyatakan Produk mempunyai pengaruh yang signifikan terhadap Keputusan membeli Frozen Food di Kota Bengkulu, diterima. Berdasarkan hasil penelitian yang dilakukan oleh sarini kodu bahwa variabel Produk secara simultan maupun parsial berpengaruh signifikan terhadap keputusan membeli. Di penelitian lain yang dilakukan oleh Ahmad Muanas (2014) menunjukkan bahwa variabel Produk memiliki pengaruh yang signifikan terhadap keputusan membeli.

\section{Pengaruh Label Halal (X4) Terhadap Keputusan membeli Y}

Label Halal memiliki pengaruh yang signifikan terhadap Keputusan Membeli. Hal tersebut dihasilkan dari hasil pengujian pada Uji t dengan nilai signifikansi yaitu sebesar ( $\operatorname{sig}<\alpha=0.000<0,05$ ) dan nilai thitung $4.757>$ ttabel 1.65847. maka H4 yang menyatakan bahwa Label Halal mempunyai pengaruh yang signifikan terhadap Keputusan membeli Frozen Food di Kota Bengkulu, diterima. Berdasarkan hasil penelitian yang dilakukan oleh Tengku Putri Lindung Bulan menyatakan bahwa Label Halal berpengaruh positif dan signifikan terhadap keputusan pembelian sosis di Kualasimpang Kabupaten Aceh Tamiang. Di penelitian lain yang dilakukan Yusuf Ardiansyah, Rois Arifin dan Rachmat S (2017) mengemukakan bahwa Label Halal berpengaruh signifikan terhadap keputusan membeli.

\section{E. Pengaruh Harga (X1), Promosi (X2), Produk (X3) dan Label Halal (X4) Terhadap Keputusan membeli Y}

Variabel Harga (X1), Promosi (X2), Produk (X3), Label Halal (X4) mempunyai pengaruh yang signifikan terhadap keputusan membeli (Y), hal ini dibuktikan Berdasarkan hasil pengelolahan data dengan uji $\mathrm{F}$ menghasilkan nilai variabel Harga (X1), Promosi (X2), Produk (X3), Label Halal (X4) yaitu sebesar (sig $<\alpha=0.000<$ 0,05) dan nilai Fhitung $51.360>$ Ftabel 3.08. Maka dapat disimpulkan bahwa Harga (X1), Promosi (X2), Produk (X3) dan Label Halal (X4), secara bersama-sama 
berpengaruh signifikan terhadap keputusan membeli Frozen Food di Kota Bengkulu, diterima. Hal ini sejalan dengan hasil penelitian yang dilakukan oleh Suzy Widyasari dan Erna Triastuti Fifilia (2009) yang menyatakan bahwa variabel Harga, Promosi, Produk dan Label Halal berpengaruh secara signifikan terhadap keputusan membeli. Penelitian lain yang dilakukan Jilly Bernadette mandey Jurnal Emba (2013) bahwa variabel Harga, Promosi, Produk dan Label Halal berpengaruh secara positif dan signifikan terhadap Keputusan membeli.

\section{PENUTUP}

Berdasarkan hasil penelitian yang telah dilakukan tentang Harga, Promosi, Produk dan Label Halal Terhadap Keputusan membeli Frozen Food di Kota Bengkulu, dapat disimpulkan sebagai berikut:

1. Variabel Harga $\left(\mathrm{X}_{1}\right)$ yaitu sebesar $\mathrm{t}_{\text {sig }} 0,012>0,05$ maka $\mathrm{H} 1$ berpengaruh signifikan terhadap keputusan membeli Frozen Food di Kota Bengkulu.

2. Variabel Promosi (X2) yaitu sebesar 0,006 > 0,05 maka H2 berpengaruh signifikan terhadap keputusan membeli Frozen Food di Kota Bengkulu.

3. Variabel Produk (X3) yaitu sebesar 0,000 > 0,05 maka H3 berpengaruh signifikan terhadap keputusan membeli Frozen Food di Kota Bengkulu.

4. Variabel Label Halal (X4) yaitu sebesar $0.000>0,05$ maka H4 berpengaruh signifikan terhadap keputusan membeli Frozen Food di Kota Bengkulu.

5. variabel Harga (X1), Promosi (X2), Produk (X3) dan Label Halal (X4) yaitu sebesar ( $\operatorname{sig}<\alpha=0,000<0,05$ ) dan nilai Fhitung $51.360>$ Ftabel 3.08. secara bersama-sama berpengaruh signifikan terhadap keputusan membeli Frozen Food di Kota Bengkulu. 


\section{DAFTAR PUSTAKA}

Abshor, M. U., Hasiolan, L. B., \& Malik, D. (2018). Pengaruh harga, promosi dan kualitas produk terhadap keputusan pembelian produk torabika duo. Journal Ekonomi Dan Bisnis, 1-15.

Amilia, S. (2017). Pengaruh Citra Merek, Harga, dan Kualitas Produk terhadap Keputusan Pembelian Handphone Merek Xiaomi di Kota Langsa. Jurnal Manajemen Dan Keuangan Unsam, 6(1), 660-669.

Aziz, N. (2019). Analisis Pengaruh Kualitas Produk, Harga, Promosi Terhadap Keputusan Pembelian Air Minum Dalam Kemasan (Amdk) Merek Aicos Produksi Pt. Bumi Sarimas Indonesia. 1-9. https://doi.org/10.31219/osf.io/w6dt5

Bulan, T., \& Rizal, M. (2016). Pengaruh Labelisasi Halal terhadap Keputusan Pembelian Sosis di Kuala Simpang Kabupaten Aceh Tamiang. Jurnal Manajemen Dan Keuangan Unsam, 5(1), 431-439.

Chusnah, A. (2020). Pengaruh Kondisi Pandemi Pada Permintaan Pasar Fast Food. Eprint UMSIDA, 191020700110.

Hendro, O., Asiati, D. I., \& Sari, D. P. (2020). Pengaruh Promosi, Terhadap Keputusan Penggunaan Layanan Digital Dimediasi Oleh Pengetahuan Konsumen Dan Kepercayaan Konsumen Di Bank Sumsel Babel Cabang Prabumulih. Islamic Banking : Jurnal Pemikiran Dan Pengembangan Perbankan Syariah, 5(2), 73-98. https://doi.org/10.36908/isbank.v5i2.117

Hpai, B. H. N. I. (n.d.). Pengaruh promosi berbasis media sosial facebook terhadap keputusan pembelian produk health food dan beverages hni hpai. 3, 936-947.

Kusuma, M. A., Agustono, \& Setyowati, N. (2020). Penelitian ini bertujuan untuk menganalisis pengaruh word of mouth, kesadaran merek, asosiasi merek, persepsi kualitas dan loyalitas merek terhadap keputusan pembelian gethuk studi kasus Gethuk Semar . Metode dasar yang digunakan dalam penelitian ini a. 4, 433-446.

Lasander, C. (2013). Citra Merek, Kualitas Produk, Dan Promosi Pengaruhnya Terhadap Kepuasan Konsumen Pada Makanan Tradisional. Jurnal Riset Ekonomi, Manajemen, Bisnis Dan Akuntansi, 1(3), 284-293. https://doi.org/10.35794/emba.v1i3.2024

Lembang, R. D. (2010). Analisis Pengaruh Kualitas Produk, Harga, Promosi, dan Cuaca Terhadap Keputusan Pembelian Teh Siap Minum Dalam Kemasan Merek Teh Botol Sosro ( Studi Kasus Pada Mahasiswa Fakultas Ekonomi S1 Reguler II). Jurnal Manajemen Pemasaran, 1(1), 69.

Memperoleh, U., Sarjana, G., Universitas, P., Semarang, N., \& Hardiyanti, L. (2017). Jurusan manajemen fakultas ekonomi universitas negeri semarang 2017.

Muna, F. N. (2019). Pengaruh Pembelian Online Dan Pembelian Offline Terhadap Keputusan Pembelian Dengan Minat Sebagai Variabel Intervening (Studi Kasus Pada 3second Yogyakarta).

Munawaroh, S. (2018). Pengaruh Promosi, Kualitas Produk Dan Kualitas Layanan Terhadap Keputusan Menabung Dengan Brand Image Sebagai Variabel Intervening. Skripsi.

Nardo, R., Evanita, S., \& Syahrizal, S. (2018). Pengaruh Kepemimpinan Transformasional, Dan Lingkungan Kerja Non Fisik Terhadap Perilaku Inovatif. JEBI (Jurnal Ekonomi Dan Bisnis Islam), 3(2), 209. https://doi.org/10.15548/jebi.v3i2.179

Nasution, N. L. (2019). Analisis Loyalitas Kerja Pegawai Dinas Pendidikan Kabupaten 
Labuhanbatu. Ecobisma (Jurnal Ekonomi, Bisnis Dan Manajemen), 6(2), 1-13. https://doi.org/10.36987/ecobi.v6i2.1

Novita, D., Astuti, L. S., Anggraini, F., \& Lestari, P. (2020). Pengaruh Promosi Menggunakan Sosial Media Terhadap Keputusan Pembelian Produk Be Glow Skincare. Seminar Nasional Riset Dan Teknologi (SEMNAS RISTEK) 2020, 161-165.

Nurohman, Y. A., \& Qurniawati, R. S. (2017). Pengaruh Komunikasi Sosial Media Terhadap Persepsi Konsumen Pada Produk Kosmetik Halal. Jurnal Among Makarti, 10(9), 1934.

Putra, A. R. (2018). Pengaruh harga, label halal, pelayanan, promosi dan lokasi terhadap keputusan pembelian: Studi kasus koperasi syariah 212 Ciputat.

Prof. Dr. Sugiyono. (2019). No Title (M. Dr.Ir.Sutopo.S.Pd (ed.)). AlFABETA,civi.

Rahardjo, C. R. (2016). Faktor Yang Menjadi Preferensi Konsumen Dalam Membeli Produk Frozen Food. Jurnal Manajemendan Start-Up Bisnis, 1(1), 32-43.

Rosdiana, E., Suharno, H., \& Kulsum, U. (2020). Pengaruh Harga, Keanekaragaman Produk, Dan Minat Beli Terhadap Keputusan Pembelian Pada Toko Online Shopee. Ekonomi Bisnis, 24(2), 13-23. https://doi.org/10.33592/jeb.v24i2.520

Soeprapto, S. R., \& Melinda, T. (2019). Dampak Media Instagram Dan Kualitas Produk Pada Minat Pembelian Frozen Empal. Media Mahardhika, 17(2), 212. https://doi.org/10.29062/mahardika.v17i2.78

Sugianto Putri, C. (2016). Pengaruh Media Sosial Terhadap Keputusan Pembelian Konsumen Cherie Melalui Minat Beli. PERFORMA: Jurnal Manajemen Dan Start-Up Bisnis, 1(5), 594.

Weenas, J. (2013). Kualitas Produk, Harga, Promosi Dan Kualitas Pelayanan Pengaruhnya Terhadap Keputusan Pembelian Spring Bed Comforta. Jurnal Riset Ekonomi, Manajemen, Bisnis Dan Akuntansi, 1(4), 607-618. https://doi.org/10.35794/emba.v1i4.2741

Wiyono, D. (2019). Pengaruh Media Sosial Facebook Dan Instagram Terhadap Keputusan Pembelian Di Home Industry (Madiun Jajan) Madiun. Simba, 2010, 867-878.

Xian, Gou Li, dkk. (2011). Pengaruh Citra Merek, Kualitas Produk, Harga, Dan Promosi Terhadap Keputusan Pembelian Kartu Perdana Telkomflexi (Studi Kasus Pada Konsumen Telkomflexi Di Kecamatan Kota Kudus Kabupaten Kudus). Jurnal Ilmu Administrasi Bisnis S1 Undip, c, 20 
Vol. 6, No. 1, Mei 2021

p-ISSN: 2541-5212 | e-ISSN: 2541-5220

J-ALIF Jurnal Penelitian Hukum Ekonomi Syariah dan Sosial

Budaya Islam 